\title{
IDENTYFIKACJA CECH INFORMACJI ZARZĄDCZEJ Z PERSPEKTYWY PROCESÓW ORGANIZACYJNO- -FINANSOWYCH W PRZEDSIĘBIORSTWIE
}

\author{
Sylwia tęgowik-Świącik, Sylwia Kowalska, \\ Małgorzata Łęgowik-Małolepsza, Izabela Turek \\ Politechnika Częstochowska, \\ Wydział Zarządzania
}

\begin{abstract}
Streszczenie: W opracowaniu podjęto problem identyfikacji cech informacji zarządczej, wskazując ich wpływ na procesy organizacyjno-finansowe w przedsiębiorstwie. Całość prezentowanych rozważań podzielono na trzy zasadnicze części. Pierwsza część opracowania eksponuje wieloaspektowość informacji w zarządzaniu przedsiębiorstwem. Druga część jest prezentacją strategicznego znaczenia zarządzania informacją w przedsiębiorstwie. Kolejna, trzecia część pracy jest odpowiedzią na pytanie badawcze. Celem opracowania jest poznanie i identyfikacja cech informacji zarządczej w procesach organizacyjno-finansowych w przedsiębiorstwie. W celu odpowiedzi na pytanie badawcze przedstawiono wyniki badań empirycznych w oparciu o studium przypadku. Wnioski z badań sugerują, iż najważniejszym czynnikiem determinującym procesy organizacyjno-finansowe jest prawidłowa selekcja informacji zarządczej, umożliwiająca podejmowanie trafnych decyzji w obszarze procesów organizacyjno-finansowych przedsiębiorstw. Metodami badawczymi zastosowanymi do realizacji celu są studia literaturowe, analiza dokumentów źródłowych oraz analiza krytyczna materiałów pozyskanych od badanego przedsiębiorstwa. Problematyka identyfikacji cech informacji zarządczej jest ważna i aktualna z uwagi na jej wpływ na zarządzanie procesami organizacyjno-finansowymi w przedsiębiorstwie.
\end{abstract}

Słowa kluczowe: procesy organizacyjno-finansowe, informacja zarządcza

DOI: 10.17512 /znpcz.2016.3.1.05

\section{Wprowadzenie}

Przedmiotem zarządzania informacją są poszczególne procesy przedsiębiorstwa. Zdaniem R. Kaplana i D. Nortona procesy zachodzące w organizacji mają umożliwiać „kreowanie wartości, która przyciągnie i zatrzyma klientów docelowego segmentu rynku oraz zapewni spełnienie oczekiwań akcjonariuszy odnośnie wyników finansowych organizacji” (Kaplan, Norton 2001, s. 43). E. Skrzypek definiuje proces jako współdziałanie ludzi, maszyn i urządzeń oraz metod działania skierowanych na wykonanie pewnego wyrobu lub usługi (Skrzypek 2002, s. 146). M. Porter rozumie proces jako łańcuch wartości, w którym poprzez realizację poszczególnych działań zwiększa się wartość zaangażowania w tworzenie lub dostarczanie produktu czy też usługi (Porter 1985, s. 3). M. Hammer i J. Champy definiują proces jako sekwencję działań realizowanych wewnątrz przedsiębiorstwa, wykonywanych w celu dostarczenia klientowi konkretnej usługi lub produktu (Hammer, Champy 1996, s. 5). $\mathrm{Z}$ powyższych definicji wynika, że proces rozumiany jest jako zestaw działań reali- 
zowanych w określonej sekwencji, które zmierzają do wytworzenia produktu o określonym akceptowalnym poziomie wartości. Przedsiębiorstwa, które chcą osiągnąć sukces na rynku, muszą działać w taki sposób, aby generować wartość dodaną, w sposób, który umożliwi wypracowywanie oczekiwanego wyniku finansowego.

Uwzględniając powyższe definicje, można przyjąć, że procesy organizacyjno-finansowe będą obejmować całokształt działań kierowniczych związanych z porządkowaniem, grupowaniem, analizowaniem i przydzielaniem do wykonania pracownikom określonych czynności na podstawie posiadanych informacji $\mathrm{w}$ celu optymalizacji działań związanych z obsługą finansową przedsiębiorstwa, związaną z jego bieżącą i przyszłą działalnością (opracowanie własne na podstawie: Penc 1997, s. 121 i 297). Dlatego autorzy niniejszego opracowania postawili pytanie badawcze: Jakie cechy informacji zarządczej istotnie wpływają na procesy organizacyjno-finansowe w przedsiębiorstwie? W konsekwencji tego pytania za cel opracowania przyjęto poznanie i identyfikację cech informacji zarządczej w procesach organizacyjno-finansowych w przedsiębiorstwie. Metodami badawczymi zastosowanymi do realizacji celu są studia literaturowe oraz analiza krytyczna materiałów pozyskanych od badanego przedsiębiorstwa.

\section{Wieloaspektowość informacji w zarządzaniu}

Pojęcie informacji jest złożone i wieloaspektowe, przez co trudno jest zdefiniować je w sposób jednoznaczny. W literaturze przedmiotu można spotkać się z różnymi definicjami terminu ,informacja”, które są rozmaicie postrzegane i interpretowane. Etymologicznie pojęcie „,informacja” pochodzi z języka łacińskiego ,informatio" i oznacza wyjaśnienie, wyobrażenie, zawiadomienie. Zdaniem J. Stonera „informacja jest wynikiem uporządkowania danych lub ich przeanalizowania w jakiś znaczący sposób" (Stoner, Freeman, Gilbert 2001, s. 589). Podobnie informację definiuje R.W. Griffin, który uważa, iż informacja „to dane przedstawione w sposób mający jakieś znaczenie" (Griffin 2000, s. 676). Według J. Madeja informacja to „wszystkie papierowe i elektroniczne bazy danych, kartoteki, dokumenty oraz dyspozycje ustne, które są generowane, przekazywane i gromadzone w systemie informacyjnym przedsiębiorstwa" (Madej 2002, s. 138). A. Skowronek-Mielczarek i Z. Leszczyński twierdzą, iż „w praktyce funkcjonowania przedsiębiorstwa za informacje można uznać dane, które po określonym przetworzeniu nabierają sensu, niosą określoną wiedzę oraz umożliwiają wyciąganie wniosków" (Skowronek-Mielczarek, Leszczyński 2007, s. 37). Wszystkie przytoczone definicje podnoszą kwestie analizy i przetwarzania treści składających się na informacje. Oznacza to, że informacja jest zbiorem przetworzonych danych, które generowane są w określonej formie i zostają przekazane w konkretnym celu.

Informacja jest pojęciem szerokim, dlatego znalazła swoje miejsce również w innych dziedzinach nauki. W ramach wiedzy o cybernetyce informacja to „treść zaczerpnięta ze świata zewnętrznego $\mathrm{w}$ procesie naszego dostosowywania się do niego i przystosowania się do niego naszych zmysłów" (Wiener 1961, s. 17). W ekonomii znaczenie informacji zostało docenione poprzez stworzenie nowej subdyscypliny - ekonomiki informacji. W piśmiennictwie ekonomika informacji 
definiuje się jako „szczegółową dyscyplinę w ramach nauk ekonomicznych stawiająca sobie za cel badania nad wpływem szeroko pojmowanej informacji na gospodarkę, identyfikującą ogólne, ekonomiczne prawidłowości tego wpływu i szukającą rozwiązań zmierzających do poprawy ekonomicznej efektywności wykorzystania informacji w procesach gospodarczych" (Czekaj, Ćwiklicki, Obora 2010, s. 47). W zarządzaniu przesłankami decyzyjnymi w przedsiębiorstwie istotne są informacje umożliwiające właściwe zrozumienie problemu decyzyjnego (Romanowska 2014, s. 138-139). Dlatego informacja zarządcza stała się ,czwartym - obok ziemi, pracy i kapitału - czynnikiem produkcji, a tym samym przedmiotem planowania, kontroli i koordynacji” (Rojek 2001, s. 174).

\section{Strategiczne znaczenie zarządzania informacją w przedsiębiorstwie}

Strategiczne znaczenie roli informacji w realizacji złożonych procesów gospodarczych stanowi przesłanki wzrostu ważności zarządzania informacją w przedsiębiorstwie. R. Zygała podaje, iż „zarządzanie informacją jest świadomym postępowaniem ludzi, zmierzającym w kierunku optymalizacji roli informacji w osiąganiu celów przez organizację" (Zygała 2007, s. 46). Funkcjonowanie przedsiębiorstw w złożonym środowisku informacyjnym charakteryzującym się dynamicznym rozwojem technologii i procesów informacyjnych wymaga tworzenia odpowiednich struktur, systemów i procedur zarządzania informacją.

Początków dziedziny wiedzy, jaką jest zarządzanie informacją, można doszukiwać się już w latach siedemdziesiątych, kiedy to termin ten zaczęto stosować najpierw w odniesieniu do kontekstu technologicznego, a następnie J. Diebold i Diebold Group opracowali koncepcję zarządzania zasobami informacyjnymi (IRM - Information Resource Management), traktując informację jako zasób. Zdaniem J. Diebolda „informacja, która w istocie jest analizą i syntezą danych, niewątpliwie będzie jednym $\mathrm{z}$ kluczowych (vital) zasobów przedsiębiorstwa lat osiemdziesiątych. Będzie ona strukturalizowana na modele do planowania i podejmowania decyzji. Będzie wykorzystana do pomiaru efektywności i zyskowności. Będzie integrowana na projekt produktu i metody marketingu. Innymi słowy mówiąc, informacja będzie traktowana jako aktywa" (Smith, Medley 1987, s. 68).

Zdaniem L. Kiełtyki „zarządzanie informacją należy rozpatrywać jako proces, który powinien zagwarantować poufność, integralność, rozliczalność, autentyczność i wiarygodność przetwarzanej informacji” (Kiełtyka 2001, s. 205). Autor uważa, iż system zarządzania informacją powinien współgrać z modelem ogólnego zarządzania oraz działania przedsiębiorstwa, z jego celami strategicznymi oraz wewnętrzną organizacją. Proces zarządzania informacją powinien być dostosowany do wielkości przedsiębiorstwa, jego obsługa winna być nieskomplikowana, powinien na bieżąco aktualizować bazy danych oraz korzystać ze źródła, jakim jest wywiad ekonomiczny. Ważne jest, aby proces zarządzania informacją był dostosowany do potrzeb wszystkich jego użytkowników, przy jednoczesnym zabezpieczeniu danych przed wykorzystaniem ich przez niepowołane osoby. Model zarządzania informacją uwzględniający ogólny model zarządzania opracował 
L. Kiełtyka. Na Rysunku 1 przedstawione zostały przykładowe systemy zarządzania informacją.

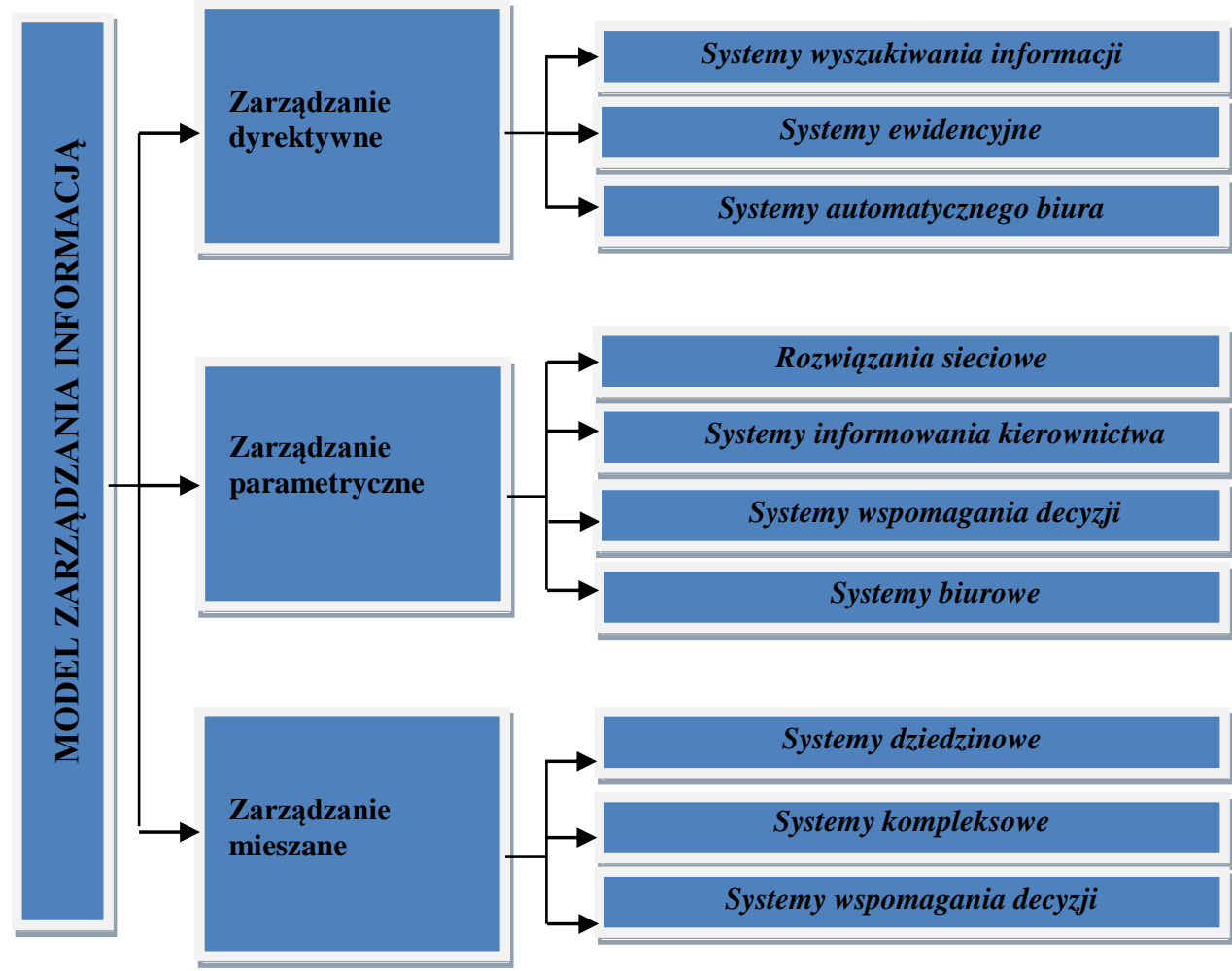

\section{Rysunek 1. Model zarządzania informacją wedlug II stopnia układu topologii systemów}

Źródło: (Kiełtyka 2001, s. 204)

Zarządzanie informacją poprzez swoją obecność w działalności przedsiębiorstwa oraz realizowanie własnych celów ma za zadanie pomóc w rozwiązywaniu wszelkich problemów (Turek 2011, s. 47-57). W praktyce zarządzanie informacją obejmuje działania związane z trzema zasadniczymi elementami przedsiębiorstwa, takimi jak: zasoby informacyjne, personel przedsiębiorstwa oraz techniczne środki przetwarzania informacji (Pawełoszek 2004, s. 193). Przy czym efektywność zarządzania informacją zależy w dużym stopniu od integralności i współpracy wymienionych czynników.

W literaturze spotykamy się z funkcjonowaniem systemów informacji strategicznej (SIS) pełniących funkcje wywiadu gospodarczego (Gierszewska, Romanowska 2003, s. 295). G.K. Świderska podaje, iż system informacji strategicznej ma „gromadzić i udostępniać informacje potrzebne do podejmowania decyzji powtarzalnych, decyzje niepowtarzalne wymagają bowiem, ze względu na wyjątkowy charakter, innego trybu gromadzenia informacji, na przykład przez zatrudnionych ekspertów" (Świderska 2003, s. 109). Podobne podejście prezentują G. Gierszew- 
ska i M. Romanowska, pisząc o budowie systemu wywiadu gospodarczego, nazywając go systemem informacji strategicznej (Gierszewska, Romanowska 2003, s. 295). Wszyscy wymienieni autorzy analogicznie traktują podmiot, którego system informacji strategicznej ma dotyczyć, a mianowicie system informacji strategicznej jest przeznaczony wyłącznie dla potrzeb decyzji powtarzalnych.

\section{Cechy informacji zarządezej o procesach organizacyjno-finansowych w badanym przedsiębiorstwie}

Identyfikację cechy informacji zarządczej o procesach organizacyjno-finansowych przeprowadzono $\mathrm{w}$ przedsiębiorstwie cementowym należącym do jednego $\mathrm{z}$ koncernów cementowych funkcjonujących w Polsce. Podczas badań $\mathrm{z}$ wykorzystaniem studium przypadku $\mathrm{w}$ pierwszym etapie prac analitycznych scharakteryzowano cechy informacji zarządczej, w drugim etapie prac analitycznych określono indykatory obszarów informacyjnych o procesach organizacyjno-finansowych badanego przedsiębiorstwa.

Przeprowadzenie procesu badawczego $\mathrm{z}$ wykorzystaniem studium przypadku pozwala na przedstawienie dokładnego i pogłębionego obrazu badanych zjawisk i relacji. Należy jednak pamiętać o ograniczonej (probabilistycznej) możliwości poznania naukowego z wykorzystaniem metody studium przypadku. Ograniczeniami studium przypadku są: mała reprezentatywność wyników, intuicyjność i subiektywność sądów, duża czasochłonność oraz wysokie koszty prowadzonych badań (Czakon 2015, s. 189-209). Studium wspiera aktualny pogląd, że szybkość i jakość informacji zarządczej determinuje proces zarządzania w przedsiębiorstwie, pozwalając na podejmowanie trafnych decyzji w obszarze procesów organizacyjno-finansowych. Do realizacji celu opracowania wykorzystano głównie studia literaturowe oraz analizę krytyczną materiałów pozyskanych od badanego przedsiębiorstwa. Problematyka informacji zarządczej nie jest nowa, ale bardzo aktualna $\mathrm{z}$ uwagi na uwarunkowania organizacyjno-finansowe, w jakich funkcjonują współczesne przedsiębiorstwa.

Zakres danych empirycznych objętych badaniem dotyczy: cech diagnostycznych obszarów informacyjnych, ich dezagregacji, wskazania metod badania obszarów informacyjnych oraz wskazania indykatorów potencjalnych i rzeczywistych zagrożeń w badanym przedsiębiorstwie. Wybór cechy informacji zarządczej, jako przedmiotu badania, został podyktowany poziomym podejściem do kategorii ekonomicznych.

Skuteczny przepływ informacji o procesach organizacyjno-finansowych w badanym przedsiębiorstwie wymaga posiadania informacji, które odpowiadają określonym potrzebom użytkowników. Cechy charakterystyczne informacji zarządczej o procesach organizacyjno-finansowych w badanym przedsiębiorstwie przedstawiono w Tabeli 1. 
Tabela 1. Cechy informacji zarządczej w procesach organizacyjno-finansowych w badanym przedsiębiorstwie

\begin{tabular}{|c|c|}
\hline $\begin{array}{l}\text { Informacja } \\
\text { zarządcza }\end{array}$ & Charakterystyka cech informacji zarządczej \\
\hline Aktualna & $\begin{array}{l}\text { Oznacza to, że przydatna informacja ma prezentować rzeczywisty i bieżący } \\
\text { obraz sytuacji bądź zdarzenia, na podstawie niej można podjąć odpowiednie } \\
\text { decyzje. Cecha aktualności informacji jest cechą szczególnie trudną do uzy- } \\
\text { skania z uwagi na upływający czas i ulotną rangę ważności informacji zarząd- } \\
\text { czej. Informacja spóźniona staje się bezużyteczna. W celu uzyskania aktualno- } \\
\text { ści informacji zarządczej w badanych przedsiębiorstwach dąży się do } \\
\text { maksymalnego skracania czasu dystrybucji opracowanej informacji. }\end{array}$ \\
\hline Dokładna & $\begin{array}{l}\text { Stopień uszczegółowienia informacji zarządczej o procesach organizacyjno- } \\
\text { finansowych ma zapewnić jej wykorzystanie w odniesieniu do szczególnych } \\
\text { sytuacji decyzyjnych. }\end{array}$ \\
\hline Istotna & $\begin{array}{l}\text { Duży wpływ na zdolność do podejmowania decyzji wywierają cechy istotności } \\
\text { i ilości informacji zarządczej. W przypadku nadmiaru informacji zarządczej } \\
\text { niezbędna jest jej selekcja. Przykładową metodą selekcji informacji jest ,zasa- } \\
\text { da } 20-80 \text { ”, zgodnie z którą jedynie } 20 \% \text { informacji docierających do kierow- } \\
\text { nictwa dotyczy problemów kluczowych i w } 80 \% \text { przesądza o skuteczności } \\
\text { procesów decyzyjnych. Cecha istotności przysparza menedżerom wielu pro- } \\
\text { blemów, gdyż informacja może mieć różny poziom istotności dla różnych } \\
\text { sytuacji decyzyjnych. }\end{array}$ \\
\hline $\begin{array}{l}\text { Wiarygodna } \\
\text { (prawdziwa) }\end{array}$ & $\begin{array}{l}\text { Cecha ta stanowi ważny czynnik decyzyjny. Długi przepływ informacyjny, } \\
\text { polegający na przepływie informacji poprzez wiele punktów przekaźnikowych, } \\
\text { może doprowadzić do przekłamań informacyjnych. Metodą weryfikacji auten- } \\
\text { tyczności informacji jest kontrola wiarygodności na każdym z punktów prze- } \\
\text { kaźnikowych. }\end{array}$ \\
\hline Pewna & $\begin{array}{l}\text { Pewność informacji zarządczej o procesach organizacyjno-finansowych polega } \\
\text { na tym, że informacja powinna wyczerpywać całokształt wiedzy o przedmiocie } \\
\text { decyzyjnym. Pewna informacja powinna minimalizować ryzyko związane } \\
\text { z działaniami podejmowanymi w procesie decyzyjnym. }\end{array}$ \\
\hline Jednoznaczna & $\begin{array}{l}\text { Informacja zarządcza o procesach organizacyjno-finansowych w badanych } \\
\text { przedsiębiorstwach powinna być odbierana zawsze w jednakowy sposób. } \\
\text { Przedmiot i autor informacji powinni być znani dla każdego odbiorcy informa- } \\
\text { cji. }\end{array}$ \\
\hline Odpowiednia & $\begin{array}{l}\text { Informacja zarządcza o procesach organizacyjno-finansowych powinna mieć } \\
\text { odpowiednią częstotliwość przepływu oraz horyzont czasowy i dotyczyć kon- } \\
\text { kretnych obszarów decyzyjnych. }\end{array}$ \\
\hline Ciągła & $\begin{array}{l}\text { Ta cecha informacji zarządczej polega na systematycznym opracowywaniu } \\
\text { i dostarczaniu informacji do decydenta. }\end{array}$ \\
\hline Przydatna & $\begin{array}{l}\text { Informacja zarządcza powinna ułatwiać decydentowi rozwiązanie określonego } \\
\text { problemu. }\end{array}$ \\
\hline Dostępna & $\begin{array}{l}\text { Informacja zarządcza powinna być gotowa do wykorzystania, we właściwym } \\
\text { czasie i we właściwym miejscu. }\end{array}$ \\
\hline $\begin{array}{l}\text { Niepowtarzająca } \\
\text { się }\end{array}$ & $\begin{array}{l}\text { Informacja zarządcza o procesach organizacyjno-finansowych nie powinna się } \\
\text { dublować, unikając wprowadzania niepotrzebnego szumu informacyjnego. }\end{array}$ \\
\hline
\end{tabular}


Sylwia Łęgowik-Świącik, Sylwia Kowalska,Małgorzata Łęgowik-Małolepsza, Izabela Turek

\begin{tabular}{|l|l|}
\hline Porównywalna & $\begin{array}{l}\text { Powinien istnieć punkt odniesienia, do którego można by się odwołać w celu } \\
\text { porównania informacji zarządczych. }\end{array}$ \\
\hline Adresowalna & Przeznaczona dla konkretnego odbiorcy. \\
\hline Elastyczna & $\begin{array}{l}\text { Elastyczność informacji zarządczej określa stopień zaspokajania potrzeb róż- } \\
\text { nych użytkowników. }\end{array}$ \\
\hline Spójna & $\begin{array}{l}\text { Cecha spójności informacji zarządczych odnosi się do większej liczby infor- } \\
\text { macji (przynajmniej dwie) i polega na tym, że informacje te muszą mieć pe- } \\
\text { wien element wspólny. }\end{array}$ \\
\hline $\begin{array}{l}\text { Pełna } \\
\text { (kompletna) }\end{array}$ & $\begin{array}{l}\text { Informacja zarządcza o procesach organizacyjno-finansowych jest pełna, jeśli } \\
\text { w całości odzwierciedla aktualny stan faktyczny problemu decyzyjnego. Kom- } \\
\text { pletna informacja stanowi zestaw informacji niezbędny do podejmowania } \\
\text { racjonalnych decyzji. Ważne jest zachowanie równowagi między zapotrzebo- } \\
\text { waniem na informację a dostarczeniem informacji do decydenta, gdyż nadmiar } \\
\text { informacji utrudnia proces podejmowania decyzji. }\end{array}$ \\
\hline
\end{tabular}

Źródło: Opracowanie własne na podstawie informacji uzyskanych od badanego przedsiębiorstwa. Do opracowania obszarów decyzyjnych wykorzystano następujące pozycje: (Kwieciński 2002, s. 33; por.: Penc-Pietrzak 2010, s. 352; por.: Stefanowicz 2004, s. 113-118)

Wymienione cechy charakteryzują użyteczność przepływających informacji zarządczych o procesach organizacyjno-finansowych w badanym przedsiębiorstwie. Odnoszą się zarówno do jakości, jak i wartości informacji zarządczych, gdyż użyteczna informacja ma zarazem wysoką jakość i wartość (niekoniecznie w sensie materialnym). Między tymi cechami występuje sprzężenie zwrotne, informacja ma wysoką jakość, jeśli ma wysoką wartość, i odwrotnie. Przepływ informacji zarządczej o procesach organizacyjno-finansowych w badanym przedsiębiorstwie $\mathrm{w}$ dużej mierze zależy od czynnika ludzkiego. $Z$ jednej strony od nadawcy informacji, czyli osoby biorącej udział w procesie decyzyjnym; z drugiej strony od odbiorcy informacji będącego jej użytkownikiem. Dla uzyskania odpowiednio wysokiej jakości przepływu informacji zarządczej bardzo ważne jest zachowanie w tej relacji szczególnej ostrożności (Tabela 2), zarówno po stronie odbiorcy w odniesieniu do szczegółowego określenia wymaganych cech jakościowych żądanych informacji, jak i po stronie nadawcy, aby zaspokoić wszystkie wymagania użytkownika.

Skuteczność przepływu informacji zarządczej o procesach organizacyjno-finansowych $\mathrm{w}$ badanym przedsiębiorstwie powinna mieć odzwierciedlenie w prawidłowym dopasowaniu informacji zarządczych do zindywidualizowanych potrzeb decydentów, ogólnym spadku kosztów zarząadzania oraz powstaniu transferu wiedzy pomiędzy użytkownikami informacji zarządczej. Przepływ informacji o procesach organizacyjno-finansowych $\mathrm{w}$ badanym przedsiębiorstwie powinien generować wzrost satysfakcji użytkowników informacji poprzez aktualizowanie wizji przepływu informacji zarządczej. W Tabeli 2 zaprezentowano cechy diagnostyczne, uwzględniające rozpoznanie indykatorów obszarów informacyjnych w procesach organizacyjno-finansowych badanego przedsiębiorstwa. 
Tabela 2. Indykatory obszarów informacyjnych w procesach organizacyjno-finansowych badanego przedsiębiorstwa

\begin{tabular}{|l|l|}
\hline $\begin{array}{l}\text { Obszar informacyjny } \\
\text { badanego przedsiębiorstwa }\end{array}$ & Zarządzanie przedsiębiorstwem \\
\hline $\begin{array}{l}\text { Cechy diagnostyczne } \\
\text { obszarów informacyjnych }\end{array}$ & Informacyjne podstawy podejmowania decyzji \\
\hline \multirow{2}{*}{$\begin{array}{l}\text { Dezagregacja cech } \\
\text { diagnostycznych }\end{array}$} & Wizja, misja i hierarchia celów \\
\cline { 2 - 2 } & Rodzaj systemu informacyjnego dla potrzeb podejmowania decyzji \\
\cline { 2 - 2 } & Rodzaj funkcji i celów realizowanych przez system informacyjny \\
\cline { 2 - 2 } & Zakres wspomagania procesów decyzyjnych \\
\cline { 2 - 2 } & $\begin{array}{l}\text { Przygotowanie pracowników wszystkich komórek organizacyjnych } \\
\text { do obsługi systemu informacyjnego }\end{array}$ \\
\hline $\begin{array}{l}\text { Wybrane metody badania, } \\
\text { analizy i oceny cech infor- } \\
\text { macyjnych przedsiębiorstwa }\end{array}$ & $\begin{array}{l}\text { Analiza dokumentacji. Analiza potrzeb informacyjnych. Metody } \\
\text { oceny efektywności SIS }\end{array}$ \\
\hline $\begin{array}{l}\text { Indykator potencjalnych } \\
\text { i rzeczywistych zagrożeń }\end{array}$ & $\begin{array}{l}\text { Wskaźniki poziomu kosztów projektowania, wdrażania i funkcjono- } \\
\text { wania SIZ. Wskaźniki efektywności względnej i bezwzględnej }\end{array}$ \\
\hline
\end{tabular}

Źródło: Opracowanie własne na podstawie informacji uzyskanych od badanego przedsiębiorstwa

W opracowaniu uwaga została zwrócona na cechy informacji zarządczej determinujące jakość jej przepływu. Przedstawiono czynniki wpływające na jakość informacji o procesach organizacyjno-finansowych $\mathrm{w}$ badanym przedsiębiorstwie oraz indykatory obszarów informacyjnych w odniesieniu do jakości przepływu informacji zarządczej o procesach organizacyjno-finansowych. Omówiony został tok postępowania w poszczególnych fazach przepływu informacji zarządczej w badanym przedsiębiorstwie.

\section{Podsumowanie}

Przedsiębiorstwa przemysłu cementowego w Polsce funkcjonują w turbulentnym otoczeniu, dlatego skuteczność procesów decyzyjnych jest uwarunkowana efektywnością przepływu informacji zarządczej. Za cel opracowania przyjęto poznanie i identyfikację cech informacji zarządczej o procesach organizacyjnofinansowych $\mathrm{w}$ przedsiębiorstwie. Z przeprowadzonych badań wynika, iż najważniejszym czynnikiem determinującym procesy organizacyjno-finansowe jest prawidłowa selekcja informacji zarządczej, która pozwala na transformację decyzji w działania, umożliwiając skuteczne podejmowanie decyzji w badanym przedsiębiorstwie. Artykuł pogłębia zrozumienie wyróżnionych cech diagnostycznych, poprzez uwzględnienie indykatorów obszarów informacyjnych o procesach organizacyjno-finansowych badanego przedsiębiorstwa. 


\section{Literatura}

1. Czakon W. (2015), Podstawy metodologii badań w naukach o zarzadzaniu, Wolters Kluwer, Warszawa.

2. Czekaj J., Ćwiklicki M., Obora H. (2010), Ekonomika informacji v. infonomika, [w:] Borowiecki R., Czekaj J. (red.), Zarzadzanie zasobami informacyjnymi w warunkach nowej gospodarki, Difin, Warszawa.

3. Gierszewska G., Romanowska M. (2003), Analiza strategiczna przedsiębiorstwa, PWE, Warszawa.

4. Griffin R.W. (2000), Podstawy zarzadzania organizacjami, Wydawnictwo Naukowe PWN, Warszawa.

5. Hammer M., Champy J. (1996), Reengineering w przedsiębiorstwie, Neumann Management Institute, Warszawa.

6. Kaplan R., Norton D. (2001), Strategiczna karta wyników - jak przełożý́ strategię na działanie, Wydawnictwo Naukowe PWN, Warszawa.

7. Kiełtyka L. (2001), Model strategii zarządzania informacja w organizacji, [w:] Borowiecki R., Kwieciński M. (red.), Zarządzanie zasobami informacji $w$ przedsiębiorstwie. Ku przedsiębiorstwu przyszłości, Wydawnictwa Naukowo-Techniczne, Warszawa.

8. Kwieciński M. (2002), Informacyjny paradygmat działalności przedsiębiorstwa, „Zeszyty Naukowe Akademii Ekonomicznej w Krakowie", nr 570.

9. Madej J. (2002), Polityka bezpieczeństwa i system ochrony informacji w przedsiębiorstwie, „Zeszyty Naukowe Akademii Ekonomicznej w Krakowie”, nr 604.

10. Pawełoszek I. (2004), Kierunki kształcenia przyszłych menedżerów informacji $w$ szkolnictwie wyższym, [w:] Nowicki A., Jelonek D., Goliński J. (red.), Informatyka ekonomiczna. Aspekty naukowe $i$ dydaktyczne, Wydawnictwo Wydziału Zarządzania Politechniki Częstochowskiej, Częstochowa.

11. Penc J. (1997), Leksykon biznesu, Agencja Wydawnicza Placet, Warszawa.

12. Penc-Pietrzak I. (2010), Zarzadzanie przeplywem informacji $w$ przedsiębiorstwie na przykładzie systemu DDM, [w:] Borowiecki R., Czekaj J. (red.), Zarzadzanie zasobami informacyjnymi w warunkach nowej gospodarki, Difin, Warszawa.

13. Porter M. (1985), Competitive Advantage, Free Press, New York.

14. Rojek T. (2001), Wartość poznawcza informacji jako strategicznego zasobu w zintegrowanym systemie zarządzania przedsiębiorstwem, [w:] Borowiecki R., Kwiecińskiego M. (red.), Zarządzanie zasobami informacji w przedsiębiorstwie. Ku przedsiębiorstwie przyszlości, Wydawnictwa Naukowo-Techniczne, Warszawa.

15. Romanowska M. (2014), Podejmowanie decyzji w organizacji, [w:] Strużycki M. (red.), Podstawy zarzadzania, Oficyna Wydawnicza SGH, Warszawa.

16. Skowronek-Mielczarek A., Leszczyński Z. (2007), Controlling - analiza i monitoring w zarzadzaniu przedsiębiorstwem, Difin, Warszawa.

17. Skrzypek E. (2002), Jakość i efektywność, Wydawnictwo UMCS, Lublin.

18. Smith A.N., Medley D.B. (1987), Information Resource Management, South-Western Publishing, Cincinnati.

19. Stefanowicz B. (2004), Informacja, Oficyna Wydawnicza SGH, Warszawa.

20. Stoner J.A.F., Freeman R.E., Gilbert D.R. (2001), Kierowanie, PWE, Warszawa.

21. Świderska G.K. (2003), Informacja zarzadcza w procesie formułowania i realizacji strategii firmy - wyzwanie dla polskich przedsiębiorstw, Difin, Warszawa.

22. Turek T. (2011), Technologia informacyjna jako instrument wymiany wiedzy $w$ przedsiębiorstwach kooperujących, „Zeszyty Naukowe Wyższej Szkoły Bankowości w Poznaniu”, nr 32.

23. Wiener N. (1961), Cybernetyka i społeczeństwo, KiW, Warszawa.

24. Zygała R. (2007), Podstawy zarzadzania informacja w przedsiębiorstwie, Wydawnictwo Akademii Ekonomicznej we Wrocławiu, Wrocław. 


\title{
IDENTIFICATION OF CHARACTERISTICS \\ OF MANAGEMENT INFORMATION FROM \\ THE PERSPECTIVE OF ORGANIZATIONAL AND FINANCAL PROCESSES IN THE COMPANY
}

\begin{abstract}
In the paper, there has been discussed the problem of identification of characteristics of management information while indicating their impact on organizational and financial processes in the company. The whole of the presented considerations has been divided into three basic parts. The first part of the paper highlights the multifaceted nature of information in business management. The second part of the paper is the presentation of strategic significance of information management in the company. The subsequent third part of the paper is the response to the research question. The aim of the paper is to learn and identify the characteristics of management information in organizational and financial processes in the company. To respond to the research question there have been presented the results of the empirical studies based on the case study. The conclusions from the research suggest that the most important factor determining organizational and financial processes is appropriate selection of management information enabling making right decisions in the area of organizational and financial processes of enterprises. The research methods applied to achieve the objective are literature studies, the analysis of source documents and the critical analysis of the materials obtained from the examined enterprise. The problem of the identification of characteristics of management information is important and up-to-date due to its impact on management of organizational and financial processes in the enterprise.
\end{abstract}

Keywords: organizational and financial processes, management information 